\title{
First report of 'Candidatus Liberibacter asiaticus' associated with Citrus decumana (Beejapuraka) in South India
}

\author{
Charith Raj Adkar-Purushothama • P. K. Maheshwar • \\ G. R. Janardhana
}

Received: 20 December 2010 / Accepted: 27 April 2011/Published online: 6 May 2011

(C) Australasian Plant Pathology Society Inc. 2011

\begin{abstract}
Candidatus Liberibacter asiaticus' was detected in Citrus decumana displaying symptoms of greening disease by direct polymerase chain reaction using universal primers specific to ribosomal protein gene of liberibacter. $100 \%$ Sequence identities were found with isolates of ' $\mathrm{Ca}$. L. asiaticus'-isolated from mandarins from Karnataka, India and more than $96 \%$ with other isolates of ' $\mathrm{Ca}$. L. asiaticus' reported elsewhere.
\end{abstract}

Keywords Liberibacter - Citrus decumana - Greening · HLB $\cdot$ Ribosomal protein gene $\cdot$ PCR

Citrus decumana (beejapuraka in Sanskrit) is an Ayruvedic medicinal plant (Indian traditional medicine) which produces large fruit resembling grapefruit and is mainly cultivated in Southeastern Asia. It is used as antioxidant, anti-inflammatory and analgesic agent (Sood et al. 2009). Citrus huanglongbing (HLB, ex greening) is one of the most serious, destructive

C. R. Adkar-Purushothama • G. R. Janardhana $(\bowtie)$

Molecular Phytodiagnostic Laboratory,

Department of Studies in Botany, University of Mysore,

Manasagangothri,

Mysore 570 009, India

e-mail: grjbelur@gmail.com

P. K. Maheshwar

Department of Microbiology, Yuvaraja's College,

University of Mysore,

Mysore 570 006, India

Present Address:

C. R. Adkar-Purushothama

Plant Pathology laboratory,

Faculty of Agriculture and Life science, Hirosaki University,

Hirosaki, Japan and widespread diseases of citrus cultivars in Asia, Africa and American continents (Adkar-Purushothama et al. 2009). It is associated with three uncultured phloem-restricted bacteria 'Candidatus Liberibacter asiaticus', Candidatus Liberibacter africanus' and 'Candidatus Liberibacter americanus', which are the members of the alpha subdivision of the proteobacteria (Jagoueix et al. 1994). In South India, the Karnataka state is the home for many citrus cultivar. Adkar-Purushothama et al. (2009) has characterized a ' $\mathrm{Ca}$. L. asiaticus' associated with mandarins in this region. Citrus decumana plants cultivated in alone with and near mandarins showed HLB symptoms (Fig. 1)and the association of a liberibacter was suspected.

From both HLB symptomatic (07 samples) and asymptomatic (03 samples) leaf samples total nucleic acid was extracted according to Adkar-Purushothama et al. (2007). The samples were tested for liberibacter infection using polymerase chain reaction (PCR) with the primer pair A2/J5 to amplify a partial sequence of $\beta$-operon (rplKAJL-rpoBC operon) ribosomal protein ( $\beta \mathrm{rp)}$ genes (Hocquellet et al. 1999) with expected amplicon size of 700 bp. Reaction mixture without template DNA served as negative controls. A product of the expected (700 bp) size were identified from all symptomatic samples and not from the symptomless samples and the negative control. A representative 700 bp PCR product was cloned, sequenced and deposited in GenBank (Accession no. HM856661). The $\beta$-rp nucleotide sequence of the liberibacter identified in Citrus decumana shared $100 \%$ sequence identity with that of the ' $\mathrm{Ca}$. L. asiaticus' isolated from mandarins from the state of Karnataka (FJ827778, FL827780) and 96\% sequence homology with ' $\mathrm{Ca}$. L. asiaticus' isolates reported elsewhere. This indicates the presence of single type of liberibacter isolate is associated with similar symptoms in different citrus species in the same region. Further ' $\mathrm{Ca}$. L asiaticus.' 


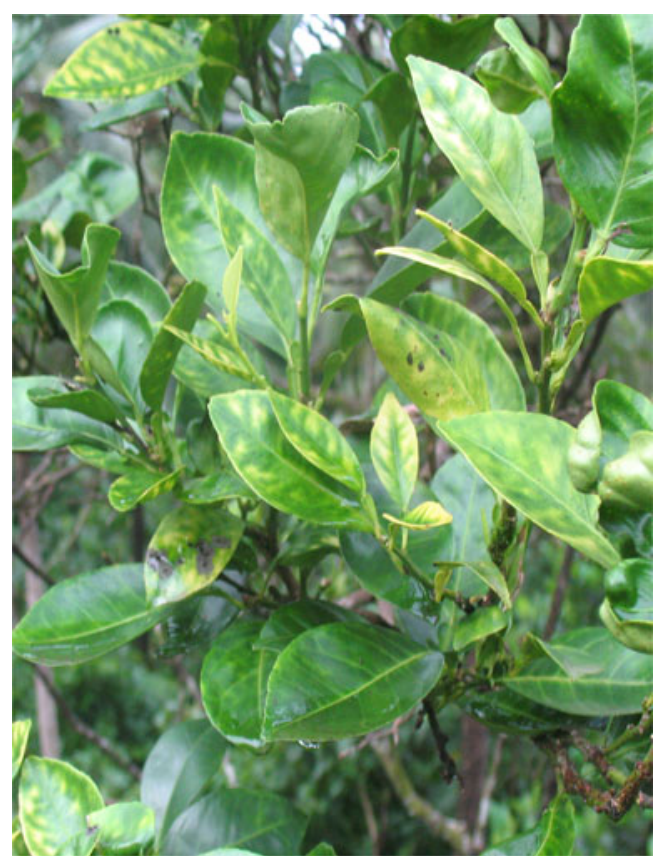

Fig. 1 Citrus decumana plant showing typical HLB symptoms

reported in the present study showed $94-96 \%$ sequence identity with ' $\mathrm{Ca}$. L. africanus', and $93 \%$ with ' $\mathrm{Ca}$. L. americanus' isolates. To the best of our knowledge this is the first molecular evidence for the association of a liberibacter with a HLB disease of Citrus decumna and the identification of a ' $\mathrm{Ca}$. L. asiaticus'-related strain associated with such disease in South India.

\section{References}

Adkar-Purushothama CR, Gottravalli-Ramanayaka J, Sano T, Casati P, Bianco PA (2007) Are phytoplasmas the etiological agent of yellow leaf disease of Areca catechu in India? B Insectol 60:161162

Adkar-Purushothama CR, Quaglino F, Casati P, Ramanayaka JG, Bianco PA (2009) Genetic diversity among 'Candidatus Liberibacter asiaticus' strains based on Single Nucleotide Polymorphisms in 16S rRNA and Ribosomal protein genes. Ann Microbiol 59:681688

Jagoueix S, Bové JM, Garnier M (1994) The phloem-limited bacterium of greening disease of citrus is a member of the alpha subdivision of the proteobacteria. Int J Syst Bacteriol 44:379-368

Hocquellet A, Toorawa P, Bove JM, Garnier M (1999) Detection and identification of the two 'Candidatus liberobacter' species associated with citrus huanglongbing by PCR amplification of ribosomal protein genes of the ßoperon. Mol Cell Probe 13:373379

Sood S, Arora B, Bansal S, Muthuraman A, Gill NS, Arora R, Bali M, Sharma PD (2009) Antioxidant, anti-inflammatory and analgesic potential of the Citrus decumana L. peel extract. Inflammopharmacol $17: 267-274$ 